\title{
Social economic development in the prevention of global blindness
}

\author{
Viet H Ho, Ivan R Schwab
}

\begin{abstract}
Aims-To assess the relation between a country's economic developmental status and its prevalence of blindness.

Methods-Available epidemiological data on worldwide visual loss and its causes compiled by the World Health Organization were reviewed. Findings were compared with economic development data from the involved countries and regions. Analysis was completed in view of the socioeconomic status of each country and region.

Results-Analysis of the global distribution of blindness indicates a trend of higher prevalence existing in developing countries with lower per capita income. Preventable causes of blindness (that is, cataract, trachoma) are also more prevalent in these countries.

Conclusions-Because economic development is shown to be a factor in blindness, programmes for blindness prevention should not be the only route to the elimination of unnecessary blindness throughout the world. Concomitant economic development is also necessary to reduce and eventually eradicate much of the preventable and avoidable causes of blindness.

(Br f Ophthalmol 2001;85:653-657)
\end{abstract}

Worldwide, there are about 150 million people that are visually disabled. ${ }^{1}$ Population based studies in various countries coordinated by the World Health Organization (WHO) programme for the prevention of blindness have estimated that approximately 38 million are blind and an additional 110 million have severely impaired vision. ${ }^{1}$ Blindness in the world is still increasing by one to two million cases a year. ${ }^{2}$ The WHO indicates that blindness will experience an accelerated growth and a probable doubling by the year 2020 unless sufficient resources for its prevention are made available. ${ }^{2}$

WHO and various international donor agencies have launched Vision 2020: the right to sight - a global initiative to eliminate avoidable blindness by the year $2020 .^{2}$ Their attempt is to increase the number of trained eyecare professionals, improve service accessibility, and procure appropriate technologies. The grand development of these programmes is thought to be necessary and will help mitigate the global burden of blindness. However, such coordination efforts focus mainly on allocation of resources and services. Other economic factors such as poverty may also contribute to blindness.
The role of economic development as it may relate to blindness has not been previously assessed. Overall, data show that more than $90 \%$ of all blind people live in developing countries. ${ }^{2}$ Patterns of blinding disorders differ between countries that are less economically developed and those that have a stronger economic infrastructure. ${ }^{1}$ Hence, it is conceivable that factors such as economic development strongly influence the population of blind people in each country. In this investigation, we explore the relation between the prevalence of blindness and economic development.

\section{Materials and methods}

In 1978, the WHO programme for the prevention of blindness (PBL) created a global blindness data bank (BDB) to obtain more detailed knowledge about blindness and its causes worldwide. The development and application of a population based assessment methodology in an increasing number of countries has led to a gradual accumulation of epidemiologically reliable data, with updated information having been published several times. Details of the survey methods for such data have been described elsewhere. ${ }^{3}$

In this investigation, we evaluate the most recent update of published data on blindness from some 60 separate countries. ${ }^{4}$ We identified the blindness prevalence from various reference areas of each given country. Blindness was defined by the International Classification of Diseases 10th revision (ICD-10) as visual acuity $<3 / 60{ }^{4}$

The gross national product (GNP) per capita income was used as a measure of each country's economic status. These data were gathered from statistical resources published by the United Nations. ${ }^{5}$ Because the collection of blindness data varied by the year in which the study was done, the source year of economic data was chosen to match that of the established blindness data.

All values were entered into a spreadsheet using software from Microsoft Excel. All figures were generated using the functions from this software program. We used the trend line function to create a regression line from a scatter plot of the data (Figs 1-3). The software program calculated the coefficient of determination, or $\mathrm{R}^{2}$ value, of the regression line.

We also compared the blindness prevalence and economic data by regions. These regions are composed of the 229 countries/territories/ economies registered worldwide and are grouped as proposed in the World Development Report, $1993 .{ }^{6}$ Owing to the lack of complete economic data on all 229 countries/territories/ 
Table 1 Blindness prevalence and economic data for countries used in study, countries grouped by economic region *

\begin{tabular}{|c|c|c|c|c|c|}
\hline Economic region & Country & $\begin{array}{l}\text { Source } \\
\text { year }\end{array}$ & $\begin{array}{l}\text { Country } \\
\text { population } \\
\text { (million) }\end{array}$ & $\begin{array}{l}\text { GNP per } \\
\text { capita } \\
\text { (US\$) }\end{array}$ & $\begin{array}{l}\text { Blindness } \\
\text { prevalence } \\
(\%)\end{array}$ \\
\hline Established market economies (EME) & $\begin{array}{l}\text { Australia } \\
\text { France } \\
\text { Ireland } \\
\text { Italy† } \\
\text { USA } \\
\text { UK† }\end{array}$ & $\begin{array}{l}1992 \\
1985 \\
1990 \\
1989 \\
1990 \\
1982\end{array}$ & $\begin{array}{l}17.085 \\
56.44 \\
3.503 \\
57.663 \\
249.975 \\
57.395\end{array}$ & $\begin{array}{l}17179 \\
9482 \\
12996 \\
15247 \\
21857 \\
8156\end{array}$ & $\begin{array}{l}0.1 \\
0.2 \\
0.5 \\
0.14 \\
0.5 \\
0.2\end{array}$ \\
\hline Other Asia and islands (OAI) & $\begin{array}{l}\text { Cook Islands } \\
\text { Indonesia† } \\
\text { Kiribati } \\
\text { Korea, Republic of } \\
\text { Mongolia } \\
\text { Myanmar } \\
\text { Nepal† } \\
\text { Papua New Guinea } \\
\text { Philippines } \\
\text { Solomon Islands } \\
\text { Sri Lanka† } \\
\text { Thailand† } \\
\text { Tonga } \\
\text { Vanuatu† } \\
\text { Vietnam } \\
\text { Samoa }\end{array}$ & $\begin{array}{l}1992 \\
1982 \\
1992 \\
1980 \\
1992 \\
1990 \\
1980 \\
1992 \\
1983 \\
1992 \\
1982 \\
1983 \\
1991 \\
1989 \\
1986 \\
1992\end{array}$ & $\begin{array}{l}0.019 \\
178.232 \\
0.07 \\
42.797 \\
2.124 \\
41.609 \\
18.916 \\
3.915 \\
61.48 \\
0.316 \\
17.002 \\
55.853 \\
0.099 \\
0.151 \\
66.312 \\
0.165\end{array}$ & $\begin{array}{l}3723 \\
531 \\
453 \\
2071 \\
479 \\
580 \\
143 \\
1068 \\
631 \\
609 \\
325 \\
808 \\
1537 \\
966 \\
118 \\
728\end{array}$ & $\begin{array}{l}0.5 \\
1.2 \\
0.5 \\
0.1 \\
1.5 \\
0.5 \\
0.8 \\
0.5 \\
0.8 \\
0.5 \\
0.3 \\
1.1 \\
0.6 \\
0.4 \\
0.9 \\
0.3\end{array}$ \\
\hline Formerly socialist market economies (FSE) & Bulgaria & 1993 & 8.823 & 1262 & 0.5 \\
\hline Sub-Saharan Africa (SSA) & $\begin{array}{l}\text { Benin† } \\
\text { Burkina Faso } \\
\text { Cameroon } \\
\text { Chadt } \\
\text { Congo† } \\
\text { Ethiopia } \\
\text { Gambia† } \\
\text { Ghana } \\
\text { Kenya† } \\
\text { Malawi } \\
\text { Mali } \\
\text { Niger† } \\
\text { Nigeria } \\
\text { South Africa } \\
\text { Tanzania } \\
\text { Togo } \\
\text { Zambia } \\
\text { Zimbabwe† }\end{array}$ & $\begin{array}{l}1990 \\
1984 \\
1992 \\
1985 \\
1989 \\
1989 \\
1986 \\
1991 \\
1981 \\
1983 \\
1985 \\
1990 \\
1989 \\
1985 \\
1985 \\
1985 \\
1978 \\
1981\end{array}$ & $\begin{array}{l}4.74 \\
9.016 \\
11.739 \\
5.68 \\
2.276 \\
51.18 \\
0.875 \\
14.87 \\
24.16 \\
8.507 \\
8.46 \\
7.666 \\
96.203 \\
35.919 \\
24.517 \\
3.638 \\
8.111 \\
9.805\end{array}$ & $\begin{array}{l}394 \\
116 \\
1013 \\
155 \\
1121 \\
126 \\
204 \\
453 \\
323 \\
180 \\
146 \\
324 \\
327 \\
1673 \\
315 \\
244 \\
676 \\
684\end{array}$ & $\begin{array}{l}0.6 \\
0.8 \\
1.2 \\
2.3 \\
0.3 \\
1.37 \\
0.7 \\
1.7 \\
0.7 \\
1.3 \\
1.3 \\
1.3 \\
3.3 \\
0.6 \\
0.8 \\
1 \\
1.43 \\
1.2\end{array}$ \\
\hline Latin America and the Caribbean (LAC) & $\begin{array}{l}\text { Costa Rica† } \\
\text { Peru }\end{array}$ & $\begin{array}{l}1986 \\
1983\end{array}$ & $\begin{array}{l}2.807 \\
21.663\end{array}$ & $\begin{array}{l}1620 \\
1072\end{array}$ & $\begin{array}{l}0.2 \\
1\end{array}$ \\
\hline Middle Eastern crescent (MEC) & $\begin{array}{l}\text { Egypt } \\
\text { Malta† } \\
\text { Morocco } \\
\text { Pakistan } \\
\text { Saudi Arabia† } \\
\text { Tunisia } \\
\text { Turkey } \\
\text { Yemen, Republic of }\end{array}$ & $\begin{array}{l}1984 \\
1989 \\
1992 \\
1990 \\
1984 \\
1993 \\
1989 \\
1989\end{array}$ & $\begin{array}{l}52.061 \\
0.354 \\
25.091 \\
112.351 \\
14.87 \\
8.06 \\
56.098 \\
11.282\end{array}$ & $\begin{array}{l}984 \\
5463 \\
1141 \\
395 \\
8995 \\
1687 \\
1947 \\
906\end{array}$ & $\begin{array}{l}3.3 \\
2.6 \\
0.8 \\
1.1 \\
1.5 \\
0.8 \\
0.4 \\
0.7\end{array}$ \\
\hline India & India† & 1989 & 849.515 & 337 & 0.7 \\
\hline China & China & 1987 & 1333.698 & 280 & 0.4 \\
\hline
\end{tabular}

*See World development report, 1993.

†Countries in which blindness prevalence data were estimated from entire country population.

economies, we calculated the total regional per capita using data from only those countries for which blindness data were available. The average regional per capita value was also attained from only the involved countries. Likewise, the regional number of blind and regional blindness prevalence data reflect only the involved countries.

The global distribution of blindness by major causes (cataract, trachoma, glaucoma, and other) has previously been reported by Thylefors et al. ${ }^{1}$ Here, we show the distribution by economic regions (Fig 4).

\section{Results}

A total of 53 countries possessed data that met the definition criteria for blindness (Table 1). Of these, only 22 countries had blindness prevalence that was estimated from the entire population of the country. In the remaining 31 countries, population based studies were done for one or more predetermined reference areas within the country. Data from the largest survey population were chosen as the representative prevalence values from those countries with multiple data.

For the 22 countries previously mentioned (with entire country estimates), the relation between the prevalence of blindness and level of economic development of each country was studied (Fig 1). A regression or "best fit" line has been plotted. The $\mathrm{R}^{2}$ value ( 0.11 in Fig 1 ) measures the amount of variation in the blindness prevalence that is accounted for by the per capita income. The correlation coefficient, $r$ value, of the regression line indicates how well 


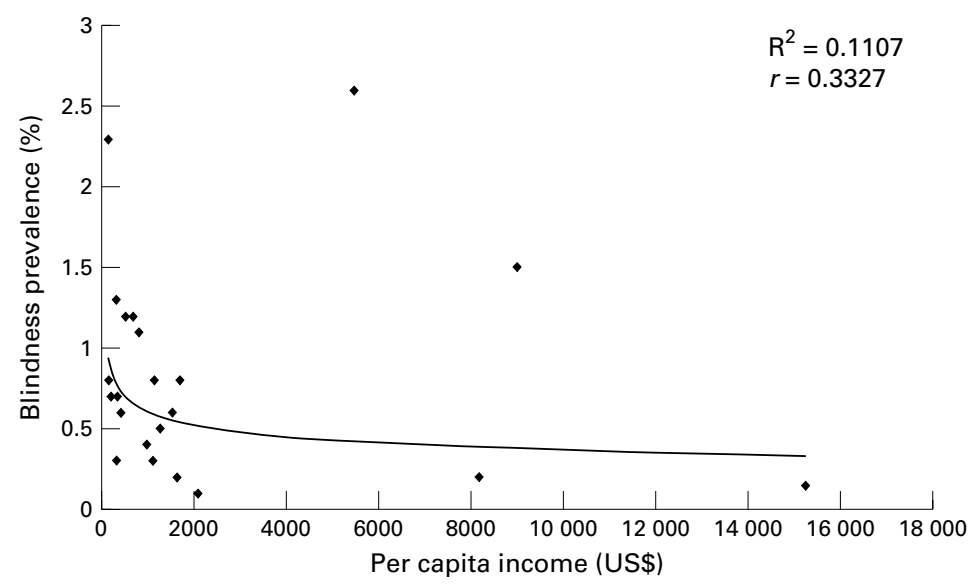

Figure 1 Prevalence of blindness versus per capita income, per country. Data taken from 22 countries with "whole country" estimates.

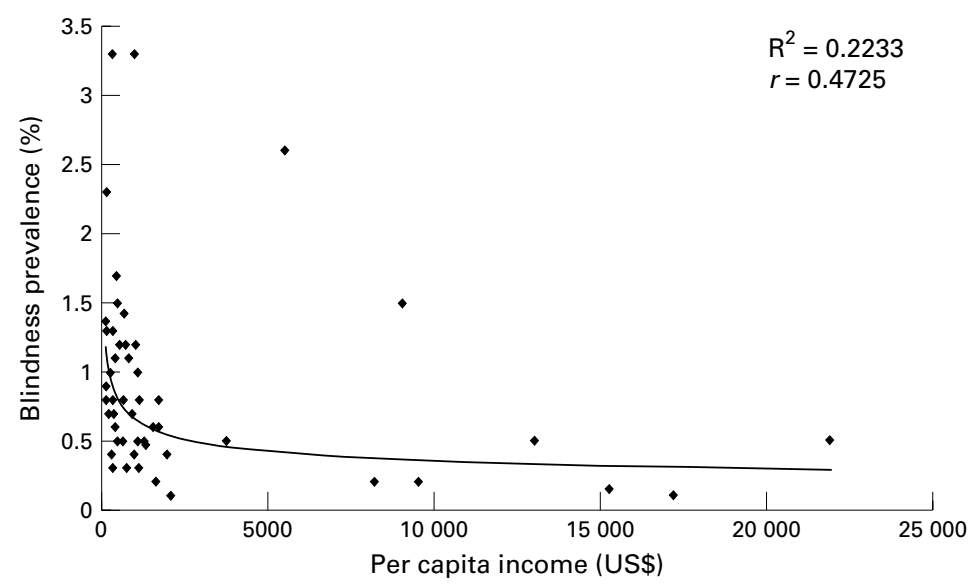

Figure 2 Prevalence of blindness versus per capita income, per country. Data taken from all 53 countries in the study.

Table 2 Global distribution of blindness and economic data, by economic region*

\begin{tabular}{lllll}
\hline Economic region & $\begin{array}{l}\text { Total regional per } \\
\text { capita (US\$) }\end{array}$ & $\begin{array}{l}\text { Average regional } \\
\text { per capita (US\$) }\end{array}$ & $\begin{array}{l}\text { Number of blind } \\
\text { (millions) }\end{array}$ & $\begin{array}{l}\text { Blindness } \\
\text { prevalence (\%) }\end{array}$ \\
\hline SSA & 33052 & 751 & 7.1 & 1.4 \\
India & 360 & 360 & 8.9 & 1 \\
OAI & 134372 & 3732 & 5.8 & 0.8 \\
China & 342 & 342 & 6.7 & 0.6 \\
MEC & 133623 & 4772 & 3.6 & 0.7 \\
LAC & 174238 & 4149 & 2.3 & 0.5 \\
EME & 601706 & 20748 & 2.4 & 0.3 \\
FSE & 50339 & 4195 & 1.1 & 0.3
\end{tabular}

All data based on 1990 values.

SSA = sub-Saharan Africa; OAI = other Asia and islands; $M E C=$ Middle Eastern crescent LAC = Latin America and Caribbean; EME = established market economies; FSE = former socialis economies.

^See World development report, 1993.

each country's economic development is associated with its blindness prevalence. The $r$ value was 0.33 for data taken from "whole country" studies. A similar relation was found for data from all 53 countries, with an $\mathrm{R}^{2}$ value of 0.22 and an $r$ value of 0.47 (Fig 2). This higher value reflects the inclusion of extended data from studies done in reference areas of each country.

Total estimated cases of blind, blindness prevalence, and per capita incomes were compiled by regions (Table 2). The regional per capita income as it relates to the prevalence of blindness in each region showed an inverse relation (Fig 3). The $\mathrm{R}^{2}$ value of 0.44 and $r$ value of 0.67 was calculated. The relative importance of cataract, trachoma, glaucoma, onchocerciasis, and other disorders leading to blindness (diabetes, macular degeneration, etc), is depicted for each region (Fig 4). Cataract is seen as the most important cause of blindness in developing regions, whereas "other" causes of blindness relatively dominate in regions that are more economically developed.

\section{Discussion}

Strict adherence to the predefined parameters of total country estimates of blindness and per capita income yielded less correlation than expected (Fig 1). Even including those countries that had accurate data from reference areas, the correlation was less than expected (Fig 2). However, the indication of an inverse relation does exist between the prevalence of blindness and economic development. Several outlying points on each figure contribute the variance from the trend line. Because blindness prevalence data were produced through estimates using models/algorithms, it is plausible that such factors as reporting biases and inconsistent data collection methods can explain the discrepancy.

The magnitude of global blindness and its major causes have been estimated by Thylefors et al, whereby they examined the blindness distribution according to eight economic regions. ${ }^{1}$ We used these data of blindness prevalence and compared them with the economic development per region, which showed a surprisingly good inverse association between the total number of blind and the economic status of each region (Fig 3).

The impact of economic development has previously been thought to be associated with lower prevalence of blindness worldwide. $.^{2} 36-9$ However, a comprehensive analysis of a direct correlation has not been completed. Currently, the majority of the world's population lives in rural areas of less developed countries. Characteristics of developing nations are high birth rates and infant mortality rates, and high rates of curable and preventable blindness. ${ }^{7}$ Socioeconomic development brings forth improvements in the standard of living, environmental sanitation, and public hygiene. This comparative review of the available data on blindness supports the evidence that blindness is more prevalent in less well developed countries.

The analogous impact of socioeconomic development can account for the progress made in the reduction of diseases such as trachoma and leprosy. Families with low socioeconomic status, poor water supplies, and suboptimal hygiene practices characterise areas in which trachoma is endemic. West et al have reported extensively on the association between such factors and the prevalence of trachoma in central Africa. ${ }^{10-12}$ Even earlier authors such as Duke-Elder suggested that economic constituents such as poverty and malnutrition correlate with higher prevalence of trachoma. ${ }^{13}$ These observations have led to the acceptance that regression of trachoma in many regions of the world has occurred with 


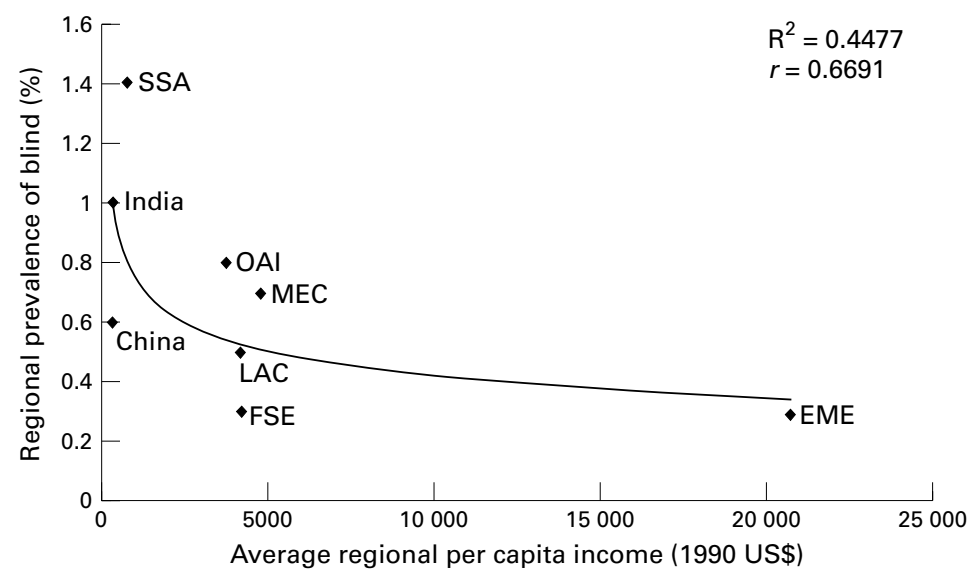

Figure 3 Prevalence of blindness versus average per capita income, by economic region $S S A=$ sub-Saharan Africa; $O A I=$ other Asia and islands; $M E C=$ Middle Eastern crescent; LAC = Latin America and Caribbean; FSE = former socialist economies; EME = established market economies.

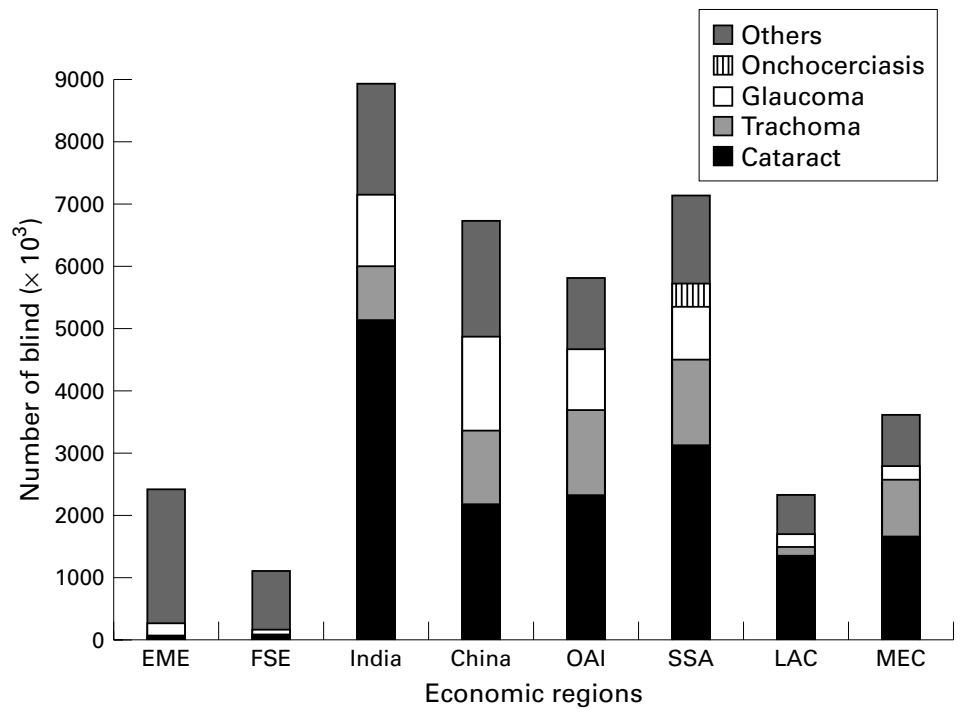

Figure 4 Global distribution of blindness and its major causes, by economic region. EME = established market economies; FSE = former socialist economies; $O A I=$ other Asia and islands; SSA = sub-Saharan Africa; LAC = Latin America and Caribbean; MEC = Middle Eastern crescent. cataract is more prevalent in developing countries where it may occur at an earlier age than in developed countries. ${ }^{8}$ And while the exact causes of cataract are not presently known, poor nutrition in childhood, shorter life expectancy, and even light damage (infrared and ultraviolet radiation) have been implicated as risk factors. ${ }^{819}$ Mutations associated with congenital cataracts in children have long suggested a genetic influence in adult onset cataracts. ${ }^{20}$ With recent studies by Hammond et al demonstrating the importance of genetic effects in such a clearly age related disease as nuclear cataract formation, ${ }^{21}$ further understanding of specific genetic defects are being explored. Genetic factors aside, diseases like xerophthalmia, other nutritional causes of blindness, and nutritional influences on cataract can be eradicated with improvement in socioeconomic development. Similarly, trachoma, a blinding disease associated with poverty and inadequate sanitation, can also be controlled with economic improvements. However, it is less convincing that pure economic development will have a significant effect on the rates of onchocerciasis, unless fly eradication or control programmes are considered to be a part of economic development. Similarly, glaucoma is a worldwide problem in all populations that requires more complex intervention strategies and will probably not change dramatically with economic development. In fact, with economic development leading to increased longevity, the prevalence of glaucoma in the developing countries may actually increase in relative and absolute terms.

Resources, both material and financial, are severely limited in developing countries where most people live beyond the reach of health and social services. The per capita income (US\$) in less developed countries is below $\$ 635$, compared with $\$ 7911$ or more, in the more developed nations. ${ }^{6}$ A critical stage of economic development may exist whereby the prevalence of preventable blindness becomes significantly less. The correlation suggested by this investigation (Figs 1 and 2) would appear to be near a per capita income of approximately $\$ 2000$. Potentially, the economic development in nations and/or regions with a per capita income of less than $\$ 2000$ could dramatically reduce the impact of preventable blindness.

\section{Conclusion}

The apparent association between the increased prevalence of blindness and poor economic development in developing countries suggests that emphasis and resources should be directed towards the development of those economies to successfully eliminate the preventable and curable causes of blindness. Though the solitary development of blindness prevention programmes by the WHO are well intended and most appropriate on a humanitarian basis, these efforts unaccompanied by other support measures will only serve to temporarily reduce the current backlog of world blindness. We believe that prevention schemes alone will not rid the global burden of 
blindness. Rather, preventive measures in conjunction with economic development is the most prudent approach to further the success of the goal of eliminating avoidable blindness throughout the world.

Supported in part by an unrestricted grant from Research to Prevent Blindness, New York, USA.

1 Thylefors B, Negrel AD, Pararajasegaram R, et al. Global data on blindness. Bull World Health Organ 1995:73:11521.

2 Thylefors B. A global initiative for the elimination of avoidable blindness. Am f Ophthalmol 1998;125:90-3.

3 Thylefors B. A simplified methodology for the assessment of blindness and its main causes. Wld Hlth Statist Quart 1987; 40:129-41.

4 Thylefors B, Negrel AD, Pararajasegaram R, et al. Available data on blindness (update 1994). Ophthalmic Epidemiol $1995 \cdot 2 \cdot 5-39$

5 Statistical Yearbook. 43rd issue. New York: Statistical Division, United Nations, 1998:147-64.

6 World Development Report 1993: investing in health. New York: published for the World Bank. New York: Oxford University Press, 1993.

7 Schwab L, Taylor HR. Cataract and delivery of surgica services in developing nations. In: Tasman W, Jaeger EA, eds. Duane's clinical ophthalmology. Revised ed. Philadelphia: JB Lippincott, 1993;Vol 5, chapter 57.

8 Javitt JC, Wang F, West SK. Blindness due to cataract: epidemiology and prevention. Anпu Rev Public Health 1996;17:159-77.

9 Sommer A. Public health aspects of ophthalmic disease. Annu Rev Public Health 1996;17:115-9.
10 West SK, Congdon N, Katala S, et al. Facial cleanliness and risk of trachoma in families. Arch Ophthalmol 1991;109: $855-7$.

11 Lynch M, West SK, Munoz B, et al. Testing a participatory strategy to change hygiene behavior: face washing in central Tanzania. Trans R Soc Trop Med Hyg 1994;88:513-17.

12 West SK, Munoz B, Lynch $M$, et al. Risk factors for constant, severe trachoma among preschool children in Kongwa, Tanzania. Am 7 Epidemiol 1996;143:73-8.

13 Duke-Elder S, ed. System of ophthalmology. Vol 8. St Louis: CV Mosby, 1965:258-67.

14 Oliva MS, Munoz B, Lynch M, et al. Evaluation of barriers to surgical compliance in the treatment of trichiasis. Int Ophthalmol 1998;21:235-41.

15 Sommer A. Nutritional blindness: xerophthalmia and keratomalacia. In: Tasman W, Jaeger EA, eds. Duane's clinical ophthalmology. Revised ed. Philadelphia: JB Lippincott, 1993; Vol 5, chapter 59.

16 Schwab IR, Ostler HB, Dawson CR. Hansen's disease of the eye (ocular leprosy). In: Tasman W, Jaeger EA, eds. Duane's clinical ophthalmology. Revised ed. Philadelphia: JB Lippincott, 1993; Vol 5, chapter 63.

17 Saikawa K. The effect of rapid socio-economic development on the frequency of leprosy in a population. Lepr Rev 1981; 52:167-75.

18 Cossermelli-Messina W. Leprosy: statistics in the americas. 7 Rheumatol 1993;20:893-6.

19 Stilma JS, Franken S, Hogeweg M, et al. Points of action in the campaign against blindness in developing countries. Doc Ophthalmol 1991;78:285-305.

$20 \mathrm{He}$ W, Li S. Congenital cataracts: gene mapping. Hum Genet 2000;106:1-13.

21 Hammond CJ, Snieder H, Spector TD, et al. Genetic and environmental factors in age-related nuclear cataracts in monozygotic and dizygotic twins. N Engl f Med 2000;342: 1787. 